\title{
Modeling the process of future social workers training considering the goals of sustainable development
}

\author{
Nadiia Pavlyk ${ }^{1, *}$, Nataliia Seiko ${ }^{1}$, and Svitlana Sytniakivska ${ }^{1}$ \\ ${ }^{1}$ Zhytomyr Ivan Franko State University, Department of Social Technologies, 10008 Zhytomyr, \\ Ukraine
}

\begin{abstract}
The aim of the article is the theoretical development of nonformal, fundraising and bilingual models of future social sphere specialists training on the basis of the goals of sustainable development in education. The study is based on preliminary processing of European and Ukrainian documents on sustainable development, numerous scientific papers on the problem of sustainable development, theoretical developments and experimental research in the field of social sphere specialists training. Each of the developed models has passed the corresponding approbation and is supported by the author's experience of practical professional training of future social sphere specialists at the Zhytomyr Ivan Franko State University. The model of future social workers non-formal education ensures the integration of professional competencies of future social workers. Fundraising training of future social workers on the basis of sustainable development involves the use of the necessary fundraising tools to ensure the development of social capital, the formation of a society of social justice, the deployment of numerous non-governmental organizations at the global and local levels. The bilingual model provides empowerment of social workers to study, do internships, work, borrow positive experiences, participate in international projects, and collaborate with professionals in their field from around the world.
\end{abstract}

\section{Introduction}

The basic principles of education for sustainable development, according to the definition of the Strategy of Education for Sustainable Development of the United Nations Economic Commission for Europe, are the ethics of solidarity; equality and mutual respect between people, countries, cultures, generations; harmony with nature, which will meet the needs of present generations without threatening future generations.

Sustainable development is a continuous process of learning and changing with the involvement of all stakeholders and leaders' opinions of formal, non-formal, fundraising and bilingual education of future social sphere professionals. The requirement to include to the teaching and learning process methods that can motivate educators and students to change their behavior and engage in sustainable development suggests including critical

\footnotetext{
* Corresponding author: pavnad@ukr.net
} 
thinking competencies, modeling future scenarios and decision-making as key ones to education for sustainable development.

\section{Material and methods}

Modeling various aspects of future social sphere specialists training, we were driven by the goals of sustainable development and their conceptual reflection in the system of higher education. Each of the developed models has passed the corresponding approbation and is supported by the author's experience of practical professional training of future social sphere specialists at the Zhytomyr Ivan Franko State University. Theoretical generalizations of this experience formed the basis for the development of non-formal, fundraising and bilingual models of future social sphere specialists training.

In the process of research we used analytical-synthetic research methods and the modeling method as a result. The study is based on preliminary processing of European and Ukrainian documents on sustainable development [1-3], numerous scientific papers on the problem of sustainable development [4-7], as well as theoretical developments and experimental research in the field of social sphere specialists training. We define the aim of the article as the theoretical development of non-formal, fundraising and bilingual models of future social sphere specialists training on the basis of the goals of sustainable development in education.

\section{Results and Discussion}

\subsection{Non-formal education of future social workers as a tool for achieving sustainable development goals}

Non-formal education has the potential to contribute to the achievement of all Sustainable Development Goals, as it is defined as a voluntary, purposeful educational activity of civil society institutions, educational, cultural and sports institutions outside the formal content; facilitation of the processes of personal development and professionalism for the social adaptation of participants to the constantly changing environment and providing them with resources for active prosocial activities. We considered the content of non-formal education of future social workers as an additional system of formation the professional, civic and personal competencies of future social sphere specialists.

It is confirmed by a study of the implementation of the UNECE Strategy on Education for Sustainable Development from 2005 to 2015, which indicates that almost $90 \%$ of participating countries use non-formal and informal education methods as tools for providing education for sustainable development. $70 \%$ of the countries participating in the study implement non-formal education for sustainable development in the process of continuous training of professionals in the workplace [8]. Continuing education is seen as a process of acquiring competencies and qualities in accordance with societal needs to be able to adapt to changes in the social environment throughout life and is a principle of education for sustainable development [9].

Coordinating our vision of non-formal education within future social workers training with the Sustainable Development Goals - to provide education participants with knowledge and skills of sustainable development by providing them with competencies and confidence leading to a healthy and productive lifestyle in harmony with nature, social values, including gender equality and cultural diversity [8] - we identify six main goals.

The goals of sustainable development should be consistent with the results (that is) competencies of future social workers professional training. 
Competencies are difficult to describe as compulsory educational outcomes because they are difficult to teach, learn and assess in the formal learning process [10]. Instead, nonformal education, in our opinion, has a winning potential for the formation of competencies, as it is based on fundamentally different methodological principles equality in educational interaction (participation, partnership), voluntariness (conscious motivation for learning goals and outcomes, focus on changes), attention to internal changes (personal and professional confidence, active civic and social position, empathy, creativity, emotionality, respect for diversity), reliance on experience, action and social interaction, accessibility and focus on the needs of participants. Goals of sustainable development, non-formal education tools and expected results - personal and professional competencies of future social workers reflect the technological scheme "goal - activity result" and determine the content of the model of future social workers non-formal education for sustainable development (Table 1).

Table 1. Model of future social workers non-formal education for the goals of sustainable development.

\begin{tabular}{|c|c|c|c|c|}
\hline $\begin{array}{l}\text { Main goals of } \\
\text { sustainable } \\
\text { development }\end{array}$ & \multicolumn{4}{|c|}{$\begin{array}{l}\text { Good health and well-being; quality education; gender equality; decent } \\
\text { work and economic growth; reduction of inequality; peace, justice and } \\
\text { strong institutions }\end{array}$} \\
\hline $\begin{array}{l}\text { Learning } \\
\text { competencies } \\
\text { of sustainable } \\
\text { development }\end{array}$ & Learning to know & $\begin{array}{l}\text { Learning to } \\
\text { do }\end{array}$ & Learning to be & $\begin{array}{l}\text { Learning to } \\
\text { live and } \\
\text { work } \\
\text { together }\end{array}$ \\
\hline $\begin{array}{l}\text { Tools of non- } \\
\text { formal } \\
\text { education of } \\
\text { future social } \\
\text { workers }\end{array}$ & $\begin{array}{l}\text { Internet platforms } \\
\text { for non-formal } \\
\text { education; } \\
\text { educational } \\
\text { programs, } \\
\text { schools, summer } \\
\text { camps, open } \\
\text { universities, } \\
\text { reading literature } \\
\text { by profession }\end{array}$ & $\begin{array}{l}\text { Trainings, } \\
\text { professional } \\
\text { workshops, } \\
\text { seminars; } \\
\text { participation } \\
\text { in interest } \\
\text { groups; } \\
\text { festivals, } \\
\text { concerts, art } \\
\text { events; } \\
\text { project } \\
\text { activity }\end{array}$ & $\begin{array}{l}\text { Initiation and } \\
\text { implementation of } \\
\text { social projects, } \\
\text { communication } \\
\text { with specialists, } \\
\text { visiting museums, } \\
\text { libraries, galleries, } \\
\text { forum theaters, } \\
\text { interactive theaters, } \\
\text { playback theaters, } \\
\text { quests }\end{array}$ & $\begin{array}{l}\text { Volunteerin } \\
\mathrm{g}, \\
\text { education, } \\
\text { participation } \\
\text { in public } \\
\text { associations, } \\
\text { exchange of } \\
\text { experience, } \\
\text { mobility } \\
\text { programs }\end{array}$ \\
\hline \multirow{2}{*}{\multicolumn{2}{|c|}{$\begin{array}{l}\text { Current challenges: } \\
\text { internal - work with the past, } \\
\text { present, future; } \\
\text { external - validation of non-formal } \\
\text { education }\end{array}$}} & $\begin{array}{l}\text { Learning } \\
\text { from the } \\
\text { past } \\
\text { experience }\end{array}$ & $\begin{array}{l}\text { Involvement } \\
\text { modern life }\end{array}$ & $\begin{array}{l}\text { Exploring } \\
\text { alternatives } \\
\text { for the } \\
\text { future }\end{array}$ \\
\hline & & Past & Present & Future \\
\hline
\end{tabular}

The integration of educational competencies for sustainable development into the process of future social workers professional training has been implemented with the help of the Standard of Higher Education for Bachelors in Specialty 231 "Social Work" [11]. Accordingly, we attempted to integrate 4 sustainable development learning competencies (learning to know; learning to do; learning to be; learning to live and work together) and 15 general competencies (GC) defined by the Standard as mandatory for the future social workers training. 
Learning to know - understanding of social challenges at the local and global levels and the role of social work in solving them - the future social worker understands: his/her rights and responsibilities as a member of the society, the values of civil (free, democratic) society and the need for its sustainable development, the rule of law, human and civil rights and freedoms in Ukraine (GC 1); subject area and professional activity (GC 6). Learning to do - the development of skills and abilities to ensure sustainable development - the future social worker is able to: preserve and multiply moral, cultural, scientific values and achievements of the society based on understanding the history and patterns of development of the subject area, its place in the general system of knowledge about nature and society and in the development of society, technology, use different types and forms of physical activity for active recreation and leading a healthy lifestyle (GC 2); think abstractly, analyze and synthesize (GC 3); apply knowledge in practical situations (GC 4); plan and manage time (GC 5). Learning to be - the development of social partnership, pluralism, mutual understanding, peace and awareness of interdependencies - a future social worker - is a person who: communicates in the state language both orally and in writing (GC 7); uses information and communication technologies (GC 8); learns and masters modern knowledge (GC 9); searches, processes and analyzes information from various sources (GC 10); has certainty and persistence in terms of tasks and responsibilities (GC 14). Learning to live and work together - the development of personal qualities and the formation of the ability to act independently, take personal responsibility for sustainable development - the future social worker cooperates to: identify, pose and solve problems (GC 11); make informed decisions (GC 12); motivate people and move towards a common goal (GC 13); act socially responsibly and consciously (GC 15); plan and manage time (GC 5).

An important direction to increase the effectiveness of non-formal education in Ukraine is the development mechanisms for validating the results of non-formal education.

\subsection{Future social workers training for fundraising activities in the social sphere in accordance with the goals of sustainable development.}

Sustainable development goals in Ukraine (17 main goals, according to the documents of the Ministry of Economy and Trade of Ukraine, 2015) include the use of necessary fundraising tools to ensure the development of social capital, social justice society, deployment of numerous NGOs globally and locally.

To such goals we include, first of all, a few that have the most pronounced social meaning:

1) Quality education (This goal of sustainable development involves the implementation of several important tasks that include a fundraising component: 1) increasing the quality of higher education and its connection with research; 2) increasing the level of knowledge and skills necessary for further professional activity);

2) Reduction of inequality (Within the framework of realization of this goal of sustainable development it is provided to ensure the availability of social services; these services are closely linked to the social worker's ability to fundraise);

3) Sustainable development of cities and communities (This goal of sustainable development includes the task of developing and implementing local development strategies, which should involve social workers who are able to conduct fundraising activities);

4) Peace, justice and strong institutions (In the process of achieving this goal, it is planned to build public peace and social security (conflict and post-conflict) as one of the tasks of the professional activity of a social worker); 
5) Partnership for sustainable development (Within this goal it is offered to develop partnership relations of the power and business for the sake of realization of the social purposes that can be realized by means of successful fundraising projects).

The above goals of sustainable development will be effectively implemented under the condition of functioning of a professionally group of social workers and pedagogues, aimed at solving urgent social problems of numerous socially vulnerable groups in Ukraine. The professional training of such specialists for fundraising, in turn, is consistent with the goals of sustainable development within higher education institutions.

In addition, the special mission of education in the promotion of the model of sustainable development of society emphasizes the "Agenda for the XXI century" [12]. This document defines the goals and content of education for sustainable development, which are directly or indirectly related to modern fundraising and training of professionals capable of conducting fundraising activities, such as: Informing members of the society about the problems of sustainable development; The formation of a worldview that involves awareness of sustainability; Orientation of the educational process to the dialogue of the subjects of the educational process; Orientation of specialists professional training on practical solution of local social problems. Fundraising is a theoretical and practical construct that defines the methodology and techniques of finding and using resources to achieve certain goals. In turn, social fundraising, or fundraising in the social sphere determines the technology of finding and implementing resources for social protection of certain socially vulnerable segments of the population, and for local social projects to develop communities. Modeling the teaching of students for fundraising activities in the context of sustainable development in education, we presented this model in Table 2.

Table 2. Model of future social workers training for fundraising activities within educational aims for sustainable development.

\begin{tabular}{|c|c|c|c|}
\hline $\begin{array}{l}\text { Main goals } \\
\text { sustainable } \\
\text { development }\end{array}$ & \multicolumn{3}{|c|}{$\begin{array}{l}\text { Quality education; reduction of inequality; sustainable development of } \\
\text { cities and communities; peace, justice and strong institutions; partnership } \\
\text { for sustainable development }\end{array}$} \\
\hline \multirow[b]{2}{*}{$\begin{array}{l}\text { Content of future } \\
\text { social } \quad \text { workers } \\
\text { fundraising training }\end{array}$} & Formal component & $\begin{array}{l}\text { Subject: } \\
\text { "Fundraising in the } \\
\text { social sphere" }\end{array}$ & $\begin{array}{l}\text { Non-formal } \\
\text { component }\end{array}$ \\
\hline & $\begin{array}{l}\text { Forms of work with } \\
\text { elements of } \\
\text { fundraising training: } \\
\text { lectures; practical } \\
\text { training; seminars; } \\
\text { internships in social } \\
\text { institutions and } \\
\text { establishments }\end{array}$ & $\begin{array}{lr}\text { Methods } & \text { of } \\
\text { fundraising } & \text { training: } \\
\text { exercises; } & \text { game } \\
\text { teaching } & \text { methods; } \\
\text { case } & \text { method; } \\
\text { method } & \text { of } \\
\text { fundraising projects }\end{array}$ & $\begin{array}{l}\text { Forms of non-formal } \\
\text { fundraising } \\
\text { education } \\
\text { students: trainings; } \\
\text { volunteering; self- } \\
\text { education and self- } \\
\text { training }\end{array}$ \\
\hline \multirow{5}{*}{$\begin{array}{lr}\text { Indicators } & \text { of } \\
\text { realization } & \text { of } \\
\text { sustainable } \\
\text { development } \\
\text { within goals } \\
\text { framework the } \\
\text { professional training } \\
\text { of future social } \\
\text { sphere specialists to } \\
\text { fundraising activity }\end{array}$} & \multicolumn{3}{|c|}{$\begin{array}{l}\text { The level of participation of adults and youth in formal and } \\
\text { informal types of education and training; the share of educational } \\
\text { institutions where inclusive education is organized }\end{array}$} \\
\hline & \multicolumn{3}{|c|}{$\begin{array}{l}\text { Proportion of people who face discrimination and do not receive } \\
\text { adequate social support in the total population }\end{array}$} \\
\hline & \multicolumn{3}{|c|}{$\begin{array}{l}\text { Proportion of regions that have approved and implemented regional } \\
\text { development strategies and plans for their implementation, } \\
\text { developed with the participation of the community }\end{array}$} \\
\hline & \multicolumn{3}{|c|}{ Index of social unity and reconciliation } \\
\hline & \multicolumn{3}{|c|}{ Number of public-private partnership projects } \\
\hline
\end{tabular}


Students are taught the basics of fundraising can be fragmented - in the process of studying the professional subjects, and concentrated - during the study of a special course "Fundraising in the social sphere." The practical orientation of this course involves the implementation of the latest forms of learning, among which the most effective, in our opinion, are the case-method and the method of projects.

Case-method. This method involves formulating a social situation, designing a fundraising project, developing a strategy for cooperation with donors (in the form of game situations), etc. To solve the case successfully, future social workers learn to work with potential donors - make a "story for charitable support", a list of possible donors; develop appeals to a potential donor, etc. In the process of solving the above cases, students implement the project method, i.e. they create a fundraising project suitable for participation in various competitions for grant and other funding. To do this, they formulate the purpose and objectives of the project; model the annotation and expected results of the project at the level of the region, community, a person. Future social workers draw up a work plan for the fundraising project and design its budget, including the cost of staff, premises, travel and transportation, equipment, publishing costs, communications, and so on. The project developers create advertising products themselves for their social project; analyze its effectiveness and prospects for further implementation in local society.

The experience of case studies and development of fundraising projects by students allows us to conclude that in the process of training for fundraising activities should be combined both formal and informal forms and methods of teaching, as such a combination gives the most tangible effect. Training social workers over the last decade, we use both traditional (lectures; practical classes; seminars; internships in social institutions) and innovative (training; volunteering; cases; individual and group fundraising projects) forms and methods of teaching.

\subsection{Model of bilingual professional training of future social sphere specialists for sustainable development}

The relevance of bilingual professional training of future social sphere specialists for sustainable development is undeniable, as education for sustainable development (ESD) is defined as education that encourages changes in knowledge, skills, values, and attitudes to enable a more sustainable and equitable society [1]. Whereas the modern world in the last decade has begun to be characterized by intense globalization; erasing social borders between countries; actualization of social problems; increasing the number of state and non-state alternative social services created and financed by foreign investors, missions, funds, which causes the need for bilingual professional exchange and interaction; dynamics of social and educational needs of the population, before educational institutions was the task to teach a specialist capable to perform his/her professional duties in the new environment. In this regard, to expand the opportunities for future professionals to study, do internships, borrow positive experience, participate in international projects, collaborate with professionals from around the world, we offer a model of bilingual professional training of future social sphere specialists (i.e. teaching students partially or completely in a foreign language), as such a process can strengthen the professional competence of graduates in the relevant specialty (Table 3 ).

Therefore, the aim component in accordance with the model of bilingual professional training of future social sphere specialists for sustainable development is the development of bilingual professional communicative competence (ability to perform professional duties with the ability to implement communication, document management, research, professional self-development and self-improvement both native and foreign languages). 
The conceptual component of such a model includes methodological approaches and principles that are most acceptable for the implementation of the model of future social sphere professionals' bilingual professional training. In the course of modeling we singled out the main principles of bilingual professional training: general didactic, linguistic and specific.

The content component of the model in the conditions of artificial bilingualism, which is typical for Ukraine, is not determined by bilingualism and must meet the general training standards defined in educational programs for bachelors and masters of social work. Bilingual education is only an element of strengthening the content of education through the development of bilingual professional communicative competence as an additional special competence that provides expansion and deepening of professional opportunities for future social sphere specialists. We consider bilingual education as a means of forming bilingual professional communicative competence by teaching professional subjects in a foreign language, which will allow students to acquire not only communicative but also professional knowledge and skills that will further assist them not only in solving professional problems, but also will encourage personal self-determination and selfrealization.

Table 3. Model of future social sphere specialist's bilingual professional training for sustainable development.

\begin{tabular}{|c|c|c|c|c|}
\hline \multirow[b]{2}{*}{ Aim } & \multicolumn{4}{|c|}{ The need in bilingual social sphere specialists } \\
\hline & \multicolumn{4}{|c|}{$\begin{array}{l}\text { Purpose: professional training of social sphere specialists on a bilingual } \\
\text { basis }\end{array}$} \\
\hline Conceptual & \multicolumn{4}{|c|}{ Methodological approaches. Principles } \\
\hline Content & $\begin{array}{l}\text { Didactic } \\
\text { element }\end{array}$ & $\begin{array}{l}\text { Bilingual } \\
\text { semantic unit }\end{array}$ & $\begin{array}{ll}\text { One } & \text { bilingual } \\
\text { subject }\end{array}$ & $\begin{array}{l}\text { All professional } \\
\text { subjects }\end{array}$ \\
\hline Forms & $\begin{array}{l}\text { binary } \\
\text { lectures, } \\
\text { practical } \\
\text { classes, } \\
\text { frontal, group, } \\
\text { individual } \\
\text { work }\end{array}$ & $\begin{array}{l}\text { lectures, } \\
\text { practical } \\
\text { classes, } \\
\text { consultations, } \\
\text { individual and } \\
\text { pair work }\end{array}$ & $\begin{array}{l}\text { problem lectures, } \\
\text { group work, } \\
\text { interactive, } \\
\text { independent } \\
\text { activities }\end{array}$ & $\begin{array}{l}\text { thematic } \\
\text { lectures, } \\
\text { practical } \\
\text { classes, } \\
\text { individual } \\
\text { lessons, } \\
\text { consultations }\end{array}$ \\
\hline Methods & $\begin{array}{l}\text { explanatory, } \\
\text { reproductive, } \\
\text { problem- } \\
\text { solving }\end{array}$ & $\begin{array}{l}\text { soft } \\
\text { immersion, } \\
\text { speech } \\
\text { support, } \\
\text { variational } \\
\text { approximation }\end{array}$ & $\begin{array}{l}\text { problem-solving, } \\
\text { heuristic, feasible } \\
\text { tasks, soft } \\
\text { immersion, } \\
\text { variational } \\
\text { approximations, } \\
\text { interactive }\end{array}$ & $\begin{array}{l}\text { total immersion, } \\
\text { variational } \\
\text { approximations, } \\
\text { superpositions, } \\
\text { interactive }\end{array}$ \\
\hline Efficiency & \multicolumn{4}{|c|}{$\begin{array}{l}\text { Result: formed bilingual professional communicative competence of future } \\
\text { social sphere specialists }\end{array}$} \\
\hline
\end{tabular}

As the process of bilingual professional training is long enough, it was divided into four stages, each of which is characterized by the relevant features of the content of education, forms and methods of teaching. In particular, at the first stage during 1-4 semesters of study there is an introduction of didactic elements in a foreign language (i.e. learning terms and terminological word-combinations) within teaching special (professional) subjects. 
For this stage, special bilingual dictionaries of social sphere terms and expressions have been developed. At the second stage (5-8 semesters of study) the process of bilingual education is complicated and students begin to study in a foreign language not simple units (such as a term), but whole blocks of professional information, but the professional subject at this stage continues to be taught in Ukrainian. For this stage special bilingual manuals were developed. The linguistic basis built up at the previous stages gives the opportunity at the next stage (1-2 semesters of master's degree) to teach one or two subjects completely in a foreign language.

For this stage, a bilingual training manual has been developed. And at the last stage of professional training on a bilingual basis - this is the last semester of the master's degree, all professional subjects should be taught in a foreign language. It should be noted that at different stages different forms, methods, teaching aids are used. As classical teaching methods for effective professional training on a bilingual basis are not enough, special teaching methods such as variational approximations, the method of superposition have been developed. We consider the levels of formation the bilingual professional communicative competence (high, sufficient, average, low) to be an efficiency component of the model, which today is a necessary condition for sustainable development, in accordance with the sustainable development goals set by the UN in 2015. SDG 4 focuses on education, and goal 4.7 is to ensure that people acquire the knowledge and skills to promote sustainable development. Today, in the context of globalization and multiculturalization, it becomes possible only if the student develops not only professional but also "linguo-professional" competencies, which in the future will allow him/her to compete not only in the Ukrainian but also in the world labor market and be able to professional self-development and self-improvement.

\section{Conclusions}

Thus, based on the main goals of sustainable development and educational principles within this concept, we have selected three innovative models for theoretical justification that were implemented in the process of social workers training. We believe that these models are outwardly valid and meet the goals of sustainable development. Thus, the model of future social workers non-formal education ensures the integration of professional competencies of future social workers: to learn to know, to do, to be and live together.

The main tools for non-formal education of future social workers are learning from the experience of the past, involvement in public life, and exploring alternatives for the future. Fundraising training of future social workers on the basis of sustainable development involves the use of the necessary fundraising tools to ensure the development of social capital, the formation of a society of social justice, the deployment of numerous nongovernmental organizations at the global and local levels.

Both the non-formal and fundraising models require the formation of bilingual competence in future social workers to increase their competitiveness in the labor market, as education for sustainable development encourages changes in knowledge, skills, values and attitudes to ensure a more sustainable and just society.

The third bilingual model provides empowerment of social workers to study, do internships, work, borrow positive experiences, participate in international projects, collaborate with professionals in their field from around the world. All these models in unity and interconnection provide professional training of future social sphere specialists consistent with the goals of sustainable development society. 


\section{References}

1. Issues and trends in education for sustainable development. Paris: UNESCO (2018)

2. Rethinking Education: Towards a global common good? UNESCO (2015)

3. Work of the Statistical Commission pertaining to the 2030 Agenda for Sustainable Development. Resolution adopted by the General Assembly on 6 July 2017. United Nations (2017)

4. C. Power, The Power of Education: Education for All, Development, Globalization and UNESCO. London: Springer (2015)

5. O. Bernad-Cavero, N. Llevot-Calvet, New Pedagogical Challenges in the $21^{\text {st }}$ Century: Contributions of Research in Education. BoD - Books on Demand (2018)

6. O. Pometun (ed.), For preschoolers - education for sustainable development. Dnipropetrovsk: Lira (2014)

7. M. Melmann, On the way to education of the future: lessons of sustainable development. Educational comments. 7-9 (2011)

8. Ten years of the UNECE Strategy for Education for Sustainable Development. Evaluation report on the implementation of the UNECE Strategy for Education for Sustainable Development from 2005 to 2015. New York and Geneva: United Nations (2016)

9. O. Vysotska, Education for sustainable development. Dnipropetrovsk: Royal Print (2011)

10. Learning from each other. The UNECE Strategy for Education for Sustainable Development. New York and Geneva: United Nations (2009)

11. Standard of higher education for bachelors in the specialty 231 "Social work", field of knowledge 23 "Social work". Kyiv: Ministry of Education and Science of Ukraine (2017)

12. B. Burkinsky, V. Stepanov, S. Kharichkov, Economic and environmental foundations of regional nature management and development. IPREEI NAS of Ukraine. Odessa: Phoenix (2005) 